Kolias G., Biographie, [in:] Léon Choerosphactès, magistre, proconsul et patrice. Biographie - Corréspondance (texte et traduction), ed. G. Kolias, Athen 1939, p. $15-73$.

Lev Matematik i Filosof, Sočinenija, ed. et trans. T.A. Senina, Sankt-Peterburg 2017 [= Новая византийская библиотека. Источники / Novaja Vizantijskaja Biblioteka. Istočniki].

Magdalino P., In Search of the Byzantine Courtier: Leo Choirosphaktes and Constantine Manasses, [in:] Byzantine Court Culture from 829 to 1204 , ed. H. Maguire, Washington 1997, p. 146-161.

SEnINA T.A., Ellinizm v Vizantii IX veka, Sankt-Peterburg 2018 [= Новая византийская библиотека. Источники / Novaja Vizantijskaja Biblioteka. Istočniki].
SÉnina T.A., Anth. Gr. 15.12 de Léon le Philosophe comme source autobiographique, "Greek, Roman, and Byzantine Studies” 57.3, 2017, p. 713-720.

Sv. Kassija Konstantinopol'skaja, Gimny, kanony, epigrammy / T. SEnInA, Kassija Konstantinovskaja: žizn' $i$ tvorčestvo, Sankt-Peterburg 2015 [= Legenda legantur. Quadrivium издательский проект. Seria Byzantina / Legenda legantur. Quadrivium izdatel'skij proekt. Seria Byzantina].

Mirosław J. Leszka (Łódź)*

Translated by Marek Majer

${ }^{*}$ Uniwersytet Łódzki, Wydział Filozoficzno-Historyczny,
Katedra Historii Bizancjum

DOI: $10.18778 / 2084-140 X .08 .22$

\title{
LeONORA Neville, Guide to Byzantine Historical Writing, with the assist- ance of David Harrisville, Irina Tamarkina, and Charlotte Whatley, Cambridge University Press, Cambridge 2018, pp. XII, 322.
}

$\mathrm{T}$ he work under discussion has been edited by Leonora Neville, professor at the University of Wisconsin and expert in the history and culture of the Middle Byzantine period; the bibliography was compiled with the assistance of David Harrisville, Irina Tamarkina and Charlotte Whatley (p. XI). The book is conceived as a companion to Byzantine historical works written between the years 600 and 1490 . Thus, the author purposefully leaves out the Early Byzantine period as well as reaches beyond the year 1453, marking the end of the Byzantine state (p. 4-5). As regards Neville's criteria for selecting the texts to be covered the volume, she chose only those that call themselves "histories" or "chronicles", or that clearly look like such (p. 4) as well as those that ostensibly participate in traditions of Greek history writing (p. 3).

The core, entry-based part of the book is preceded by an Introduction (p. 1-44), in which the author expounds her conception of Byzantine historical literature and characterizes the community of Byzantine historians of the relevant periods: she describes the objectives they set before themselves and makes certain remarks about the intended readers of their works. Some space is also devoted to issues such as classicism, emphasis, and meaning in Byzantine historical writings, as well as to the problems of dating, nomenclature, and the language itself. The final part of the Introduction provides information on the principal series of publications in which editions of Byzantine historical sources may be found as well a basic bibliography, featuring several essential works from which - according to Neville - the reader should begin his or her study of Byzantine historiography.

The main part of the book consists of 52 entries, covering the following authors/works: Theophylakt Simokatta (p. 47-51), Paschal Chronicle (p. 52-55), George Synkellos (p. 56-60), Chronicle of Theophanes (p. 61-71), Patriarch Nikephoros (p. 72-77), Scriptor Incertus de Leo V (p. 78-80), Chronicle of 811 (p. 81-84), Megas Chronographos (p. 85-86), George the Monk (p. 87-92), Peter of Alexandria (p. 93-94), Genesios (p. 95-100), Theophanes Continuatus (p. 101-109), Constan- 
tinian Excerpts (p. 110-113), John Caminiates (p. 114-117), Symeon the Logothete (p. 118-123), Leo the Deacon (p. 124-127), Chronicle of Monemvasia (p. 128-134), Chronicon Bruxellense (p. 135-136), Psellos (p. 137146), John Xiphilinos (p. 147-149), Michael Attalaiates (p. 150-154), John Skylitzes and Scylitzes Continuatus (p. 155-161), George Kedrenos (p. 162-168), Nikephoros Bryennios (p. 169-173), Anna Komnene (p. 174-185), John Kinnamos (p. 186-190), John Zonaras (p. 191-199), Constantine Manasses (p. 200-204), Michael Glykas (p. 205-209), Eusthatios of Thessaloniki (p. 210-215), Joel (p. 216-218), Niketas Choniates (p. 219-225), George Akropolites (p. 226-231), Theodore Skoutariotes (p. 232-236), George Pachymeres (p. 237-242), Nikephoros Gregoras (p. 243248), Ephraim (p. 249-251), Constantine Akropolites the Grand Logothete (p. 252-253), Chronicle of Morea (p. 254-259), Nikephoros Kallistos Xanthopoulos (p. 260-265), John VI Kantakouzenos (p. 266-272), Michael Panaretos (p. 273-274), Chronicle of Ioannina (p. 275-277), Chronicle of Tocco (p. 278-280), John Kananos (p. 281-284), John Anagnostes (p. 285-288), Leontios Machairas (p. 289-292), Leontios Syropoulos (p. 293-297), Doukas (p. 298-301), George Sphrantzes (p. 302-307), Michael Kritovoulos (p. 308-311), Laonikos Chalkokondyles (p. 312-318). The individual entries supply the basic information on each given author/work as well as a primary bibliography, arranged in the following order: manuscripts - editions - translations ${ }^{1}$. Each entry

\footnotetext{
${ }^{1}$ It is fairly surprising that translations of the pertinent works into Slavic languages are cited most inconsistently. Thus, some of the entries mention the available translations into Russian, Czech, Bulgarian or Polish, while in certain others these are omitted completely - for no apparent reason. For instance, no mention is made of the very existence of the translations of the History by Theophylakt Simokatta - the subject of the first entry in the book - into Russian (ФЕОФИЛАКТ СИМОКАТТА, История, trans. Н.В. ПИГУЛЕВСКАЯ, Москва 1957) and Polish (Teofilakt Simokatta, $\mathrm{Hi}$ storia powszechna, trans. A. KotŁowsKA, Ł. RóżYCKI, Poznań 2016 [= Rh.ŹHB, 7]; likewise omitted is the Czech translation of the work by Laonikos Chalko-
}

also features a selection of contemporary scholarly literature, arranged according to the topics treated and with an indication of the work(s) from which it is advisable to begin studying (Starting Point). Predictably, the layout and size of the entries varies greatly, reflecting the degree of interest that a given author of work has aroused in modern scholarship. The authors of the bibliography focus predominantly on works published in western languages (especially English), no doubt a consequence of the fact that the volume is directed primarily at a western readership.

The book is capped by two appendices - A: Time Periods Covered in the Histories (p. 319-321) and B: Timeline of Authors' Lives (p. 322).

Leonora Neville's book appears to be an apt introduction to the Byzantine historiography of the $7^{\text {th }}-15^{\text {th }}$ centuries - both as a point of departure for those intending to study it more closely and as a source of information for those merely interested in acquiring a basic familiarity with the topic. Nevertheless, the work is to some extent hampered by the non-inclusion (with a small number of exceptions) of the scholarly output of Byzantinists writing in Slavic languages.

\section{BiBLIOGRAPHY}

Feofilakt Simokatta, Istorija, trans. N.V. PigulevSKAJA, Moskva 1957.

Laonikos Chalkokondyles, Poslední zápas Byzance, trans. J. Kalivoda, R. Dostálová, Praha 1988.

Teofilakt Simokatta, Historia powszechna, trans. A. KotŁowska, Ł. Różycki, Poznań 2016 [= Rhomaioi. Źródła do Historii Bizancjum, 7].

\section{Mirosław J. Leszka (Łódź)" Translated by Marek Majer}

kondyles, the last author to be treated in the volume (Laonikos Chalkokondyles, Poslední zápas Byzance, trans. J. Kalivoda, R. Dostálová, Praha 1988). * Uniwersytet Łódzki, Wydział Filozoficzno-Historyczny, Katedra Historii Bizancjum 